\title{
MENELAAH HUBUNGAN ANTARA POLITIK DAN MAHASISWA PADA ERA MODERNISASI TERHADAP IDEOLOGI POLITIK
}

\author{
Indah Nuri Lestari ${ }^{1)}$, Fadila Damayanti ${ }^{2)}$, Anita trisiana ${ }^{3)}$ \\ ${ }^{1), 2)}$ Mahasiswa Akuntansi Universitas Slamet Riyadi Surakarta \\ ${ }^{3)}$ Dosen PPKn Universitas Slamet Riyadi Surakarta
}

\begin{abstract}
ABSTRAK
Penelitian ini bertujuan untuk mengetahui hubungan antara politik dan mahasiswa pada era moderenisasi terhadap ideologi politik, di era ini gerakan mahasiswa terhadap politik bisa dikatakan terbatas atau kurang, karena hal tersebut bisa dilihat dari keikutsertaaan para mahasiswa dalam pemilu dan demokrasi lainnya. Selain itu, kurangnya pemahaman terhadap pentingnya politik dan anggapan dari setiap individu terhadap politik bahwa politik tidak akan merubah kehidupannya.Padahal partisipasi mahasiswa juga dibutuhkan apalagi sebagai penerus bangsa yang harus mempertahankan dan menjunjung tinggi ideologi negara. Metode yang digunakan adalah metode Deskriptif. Di dalam negara kita salah satu istilah yang paling kontroversial dalam setiap perkembangan pemikiran adalah ideologi politik. Dalam masyarakat luas bahkan sampai berbagai negara. Moderenisasi merupakan hasil komersialisasi dan indusrialisasi, namun proses ini berlangsung melalui dukungan birokrasi (politik). Dengan demikian variabel politik bisa dikatakan lebih penting di bandingkan ekonomi, seperti halnya di indonesia saat ini yang sedang marak kasus politik dari pada ekonomi masyarakat indonesia. Jika dibandingkan dengan negara lain yang sibuk memikirkan kemajuan dan kemakmuran ekonomi negaranya. Maka dari itu perlu diadakan sosialisasi politik terhadap seluruh mahasiswa tentang pentingnya politik dalam suatu negara.
\end{abstract}

Kata kunci : Ideologi politik, Era modernisasi, Mahasiswa. 


\begin{abstract}
This sesearch aims to knowing political relation and student in the era of moderenization for political ideology, in this era student movement for political can be seid limited or deficient, because that matter can be seen from students participation in election and other democracies. Besides, lack of understanding of the impertance of politic and the assumption of each individual to politic that politic will not change their life. Eventhough student participation is also needed, espedally as the nation's succesor who must maintain and uphold the country's ideology. In our country one of the must controversial terms in every development of thought is political ideology. In the wider community event up to various countries. Moderenization is the result of commercialization and individualization, but this procces takes place through bureaucratic support. Therefore political variable can be said to be more imperlant than economics, as is the case in indonesian, there are curiently widesprezd political cases lather than the Indonesian economy.Compared to other countries that are busy thinking about the progress and prosperity of their country's economy. Therefore, it is necessary to br held political socialization to all students on the importance of politics in a country.
\end{abstract}

Keyword : political ideology, era modernization, college student. 


\section{PENDAHULUAN}

Di dalam era moderenisasi ini terutama di negara indonesia istilah ideologi memiliki konotasi yang negatif. Selain itu ideologi juga memiliki kesamaan dengan berbagai cara,gaya, atau buah pikir paham totaliter yang tidak begitu disukai oleh banyak kalangan. Sementara itu banyak yang berpandangan bahwa ideologi sebagai bentuk propaganda politik yang salah, terlalu berlebihan dan mengadaada, dan perdebatan tentang ideologi terasa di pandang perlu oleh beberapa negara, manakala negara-negara yang bersangkutan mulai merasakan adanya ancaman eksistensinya oleh ideologi lain. Misalnya di indonesia saat ini pancasila telah diakui secara luas sebagai ideologi negara. namun, pada masalah ideologi tetsebut terasa intens pada beberapa dasawarsa akhir-akhir ini, jika dikaitkan dengan kekhawatiran, kemungkinan ideologi komunis akan kembali muncul yang akan mrngguncangkan ketatanegaraan

Sulitnya mendapatkan kesepakatan bersama mengenai pengertian ideologi antara satu dengan yang lainnya. Jika berbicara soal ideologi orang cenderung mempertentangkan antara ideologi yang di anutnya dengan ideologi yang di anut oleh oranglain.apakah yang dianut dianggap lebih tinggi nilainnya di banding apa yang dianut pihak lain. Dengan adanya hal menampakkan bahwa ideologi dibatasi suatu sistem pemikiran yang secara empiris tidak bisa di benarkan bahkan bisa dikatakan tidak tepat secara moral untuk memperdayakan orang lain . Adanya anggapan setiap pihak bahwa ideologi adalah suatu yang buruk, bisa dilihat dari penyikapan mereka terhadap hakikat manusia.dikarenakan adanya tekanan moderenisasi bangsa-bangsa baru dan perkembangan kepolitikan nasional dengan tujuan untuk meningkatkan produk sosial yang adil.

Politik mengalami proses moderenisasi yang bisa dilihat dari perbedaan-perbedaan yang sangt luas melalui metode-metode baru maupun gagasan-gagasan baru. Akhir-akhir ini metode fungsional dimanfaatkan karena tekanan yang berkenaan dengan perbandingan. Apalagi pada saat ini ideologi politik dapat menciptakan daya tarik emosional yang sangat kuat, baik terhadap pengikut atau penentangnya. Dengan demikian bisa dikatakan ideologi politik secara langsung mempengaruhi perilaku politik suatu kelompok. 


\section{METODE}

Metode yang digunakan adalah metode deskriptif. Menurut Nazir (1988:63) metode diskriptif merupakan suatu metode yang digunakan untuk meneliti status sekelompok manusia, suatu objek, kondisi, sistem pemikiran ataupun suatu kelas peristiwa pada masa sekarang. Tujuan dari penelitian deskriptif ini adalah untuk membuat diskripsi, gambaran, atau lukisan tersusun secara berurutan, berdasarkan fakta terpercaya yang sudah diselidiki.

Menurut Whintney (1960), metode deskriptif adalah proses penyelidikan fakta agar sesuai interpretasi yang tepat. Penelitian deskriptif membahas tentang permasalan di kehidupan masyarakat dan aturan yang berlaku di masyarakat dalam kondisi tertentu, seperti, hubungan di masyarakat, pelaksanaan atau kegiatan yang terjadi di masyarakat, sikap masyarakat, pandangan setiap masyarakat, serta proses yang sedang terjadi dan berpengaruh pada suatu kemasyarakatan. Dalam metode deskriptif, penelitian ini bisa membandingkan fenomena yang satu dan yang lainnya sehingga bisa disebut sebagai suatu studi komparatif. Ada saatnya peneliti mengadakan penggolongan, serta penelitian pada setiap fenomena yang terjadi dengan menetapkan suatu peraturan tertentu sehingga banyak pakar yang menyebutnya sebagai metode deskriptif dengan nama lain survei normatif (normative survey). Dengan adanya metode deskriptif ini juga diselidiki kedudukan setiap peristiwa atau factor dan melihat hubungan antar faktor. Maka dari itu metode deskriptifini juga disebut sebagai studi status.

\section{PEMBAHASAN}

Istilah ideologi politik mempunyai pengertian yang tidak sama dengan istilah filsafat politik atau teori politik.tidak jarang kita menemukan istilah secara bergantian seakan akan memiliki arti yang sama antara satu istilah dengan istilah yang lain. Kadang kadang hanya dilandasi pertimbangan untuk tidak melakukan pengulangan penyebutan secara monoton ketiganya dipakai secara bergantian sebagai simbol peristilahan yang sama.

Ideologi politik merupakan kumpulan dari beberapa prinsip yang mengarahkan pada satu tujuan, harapan, tindakan dan ide yang menjelaskan cara masyarakat seharusnya bekerja. ideologi politik biasanya membahas tentang dirinnya sendiri bagaimana cara mengatur kekuasaan dan bagaimana cara melaksanakannya,bisa dikatakan juga bahwa ideologi politik mencakup seperangkat asumsi dasar baik yang normatif maupun empiris mengenai 
sifat, tujuan manusia dan masyarakat yang bisadigunakan sebagai landasan untuk menjelaskan dan mempertimbangkan kondisi manusia sebagai pendorong dalam upaya mengembangkan serta mempertahankan tertib politik yang diidamidamkan (Wartoyo, A. Trisiana: 2017).

Sering kali ideologi itu muncul dan berkembang pada situasi yang kritis atau krisis, dimana cara berpikir dan cara pandang serta bertindak yang dianggap wajar dan umum dalam masyarakat sebagai suatu hal yang tidak bisa di terima yang mendorong munculnya suatu ideologi. Suatu ideologi akan mulai diterima sebagai hal yang wajar apabila mereka telah merasa dieksploitasi atau di campakkan. Penempatan ini dianggap penting ketika mereka sudah merasakan ancamandengan adanya perubahan fundamental dalam masyarakat.

Ideologi juga memiliki ruang lingkup jangkauan yang luas serta beragam.Ruang lingkup ini dapat dilihat dari dimensi horizontal serta penjelasannya sampai pada pandangan yang komprehensif. Selain itu,ideologi juga mencakup strata pemikiran dan panutan yang bisa dilihat dari dimensi kapital dari kompleks pemikiran dengan slogan-slogan yang sederhana dan di ekspresikan sesuai pemahaman dan komunikasi masa yang di kembangkan.

Seseorang bisa terikat dengan ideologi didasarkan pada rangsangan emosional, intelektual seperti kepentingan pribadi.Ikatan ini muncul karena adanya keinginan untuk mewujudkan ambisi pribadinya dalam keterikatan sosail.ada yang beranggapan bahwa ideologi sebagai suatu pola yang sistematis, namun tidak jarang yang mengatakan bahwa ideologi itu abstrak.

Ideologi juga bisa cenderung bersifat absolut, universal serta ekslusif. dikarenakan setiap ideologi selaras dengan pembuktian seta logika untuk mewujudkan prinsip yang di anggap benar mengenai perkembangan, keadilan dan kemajuan.jadi, ideologi bukan subyek yang bisa di tawar atau di negosiasikan.

Ideologi juga bisa di dokumentasikan dan dipersonalisasikan, ia juga menyertakan strategi-strategi apabila dilaksanakan secara terarah, serta mengubah tujuan dan ketertiban masyarakat yang bersifat programatik. Namun, seiring berkembangnya zaman pemikiran yang kuat dan kreatif di pakai sebagai landasan dari suatu ideologi. Pemikiran tentang perlunya perubahan terhadap ideologi dilator belakangi oleh upaya merasionalkan 
kegagalannya untuk mengadaptasikan keberhasilan-nya.

Ideologi terjalin gerakan politik yang terkait tindakan, maka ideologi memerlukan organisasi.Dengan adanya organisasi ini di implementasikan dan disebarkan.Konflik gagasan dalam konflik ideologi sering berbenturan ambisi dan organisasi untuk memperoleh kekuasaan manusia harus mengikatkan ideologi terhadap organisasi politik.

Semua organisasi politik yang tumbuh subur selama tahun 1960-an telah menghilang, dan beberapa organisasi politik yang baru telah menggantikan politik lama tentu dengan partai-partai politik baru juga. Relatif sedikit kaum aktivis dan mahasiswa yang ikut serta kampanye dan demonstrasi terlihat pada saat mengatur kegiatan monopolitis. Karena dengan terpecahnya dan lengkapnya SDS sebagai satu gerakan dengan basis di kampus, terdapat kesepakatan di kalangan mahasiswa radikal bahwa usaha organisasi seharusnya punya basis tempat lain seperti pekerja keras dan serikat buruh.

Mahasiswa adalah pelajar perguruan tinggi dalam struktur pendidikan di indonesia yang menduduki jenjang pendidikan tertinggi.Kampus sekarang ini tidak dapat di jadikan loncatan yang efektif untuk revolusi. Hanya sedikit pemerintahan mahasiswa yang tertarik pada masalah politik, namun dalam beberapa kasus politik dari perhatian pemerintahan mahasiswa. Jadi mahasiswa tidak menjadi entitas politik namun kesadaran politik dan kekuasaan meningkat pada tahun 1970-an.

Penurunan aktivitas politik mahasiswa di sebagian negara berkembang memang tidak setajam di negara-negara industri. Dari berbagai faktorsosial ekonomi politik cukup mengkhawatirkan kehidupan masyarakat serta mahasiswa, ketidak-adilan sosial, kebijaksanaan luar negeri yang tidak adil, ketidak puasan terhadap pemerintahan, politik yang dianggap sudah tidak demokratis yang sebagai akar dari kegiatan politik mahasiswa di berbagai negara. jadi, secara umum latar belakang itu bisa dibedakan diantara penyebab yang menyangkut semua lapisan masyarakat serta mahasiswa yang lebih merasakan penyebabnya.

Ketidak puasan mahasiswa dalam gerakan politik pecah, yang terjalindengan keresahan masyarakat. Kepuasan ini disusun berdasarkan ideologi yang ikut seta memberikan penyelesaian yang alternatif.

Pada kenyataan itu menunjuk-kan pentingnya peran ideologi dalam membangkitkan gerakan politik mahasiswa. 
Disamping semakin per-kembangan zaman ideologi dari gerakan poliyik oleh mahasiswa wataknya semakin radeikal. Hakikat gerakan politik mahasiswa yaitu untuk mengubah kondisi kehidupan yang kurangnya pengetahuan tentang politik menjadi paham dan fasih dalam dunia perpolitikan. Diperlukannya mem-pelajari situasi kampus akhir-akhir ini untuk memahami sikap dan perhatian populasi mahasiswa sekarang, namun juga menemukan penjelasan mengenai perubahan dramatis yang berlangsung bertahun-tahun. Tetapi tidak secara tepat meramalkan gerakan mahasiswa atau mengantisipasi isu politik yang dapat merangsang minat politik mahasiswayang mungkin bisa membantu untuk tidak hanya memahami apa yang telah terjadi tapi mungkin juga menyadari apa yang akan terjadi di masa yang akan datang. Pemahaman atas gerakan mahasiswa pada masa lampau harus dipusatkan untuk menemukan kesalahan serta tradisi yang harusnya dipertahankan.

Dalam tradisional aktivitas dan aktivisme organisasi mahasiswa dan pada periode saat ini merupakan periode kemandulan. Beberapa kelompok mahasiswa yang masih aktif di kampus dengan tradisi kampus yang lumayan kuat. Namun kelompok sangat kecil mempunyai pengikut yang sedikit. Pada masaynya, para mahasiswa di bangkitkan kembali pada isu politik. meski dalam kasus tersebut demonstrasi cenderung kecil dan tidak tercipta gerakan yang bertahan lama.

Kepolitikan yang mengalami proses moderenisasi diri mem-perlihatkan perbedaan-perbedaan yang luas, sehungga untuk mempelajarinya butuh metode baru maupun gagasan yang baru. Kita juga belum memiliki skema klasifikasi atau perbandingan yang berguna sehingga tidak bisa membuat analisis yang salah.

Moderenisasi merupakan sejenis harapan yang di dalamnya melekat seluruh revolusi sejarah masa lalu serta semua keinginan yang di harapkan. Moderenisasi revolusi sangat luas dan signifikan yang akibatnya bisa menakutkan. Setiap tujuan yang sangat ingin menciptakan kekuasaan politik. Aspek dinamis moderenisasi dari segi studi politik dapat dikatakan dalam proporsi umum, bahwa moderenisasi merupakan proses peningkatan kompleksitas masalah-masalah manusia dimana kepolitikan harus segera bertindak.

Kepolitikan prademokratis menjadi signifikan untuk study politik melalui analisis sistem dan bentuk politik serta melalui analisis sistem dan bentuk politik melalui study keabsahan. yang juga 
dianggap penting yaitu aspirasi dan kepercayaan umum. Mederenisasi menyediakan suatu tatanan yang berguna untuk mengungkapkan persoalan politik.

Moderenisasi juga di gambarkan dalam masyarakat non industri sebagai penggantian peran profesional,teknis, administratif srta penggantian institusi yang mendukung peran seperti sekolah,universitas, birokasi, rumah sakit.namun masyarakat non industrin kekurangan daya dorong pemersatu. Organisasi-organisasi menjadi kacau dan membingungkan. Politik menjadi mekanisme integrasi serta kewenangannya menjadi persoalan kritis yang dihadapi para pemimpin.

Moderenisasi sering dikaitkan dengan beberapa indusrti sebuah universitas atau sekolah, gereja, kementrian pemerintahan. Mereka biasa memegang peran modern. Moderenitas berarti juga sebagai kemajuan teknologi dan peralatan akumulasi pemilikan teknologi dan mesin yang rumit.

Pembangunan politik adalah bagian dari moderenisasi yang selalu melibatkan konflik yang berkelanjutan supaya sistem politik tetap stabil.Masalah konflik tersebut merupakan sesuatu yang pada pembangunannya meliputi persamaan, proses diferensiasi dan juga kebutuhan kapasitas yang lebih besar.bahwa pada setiap perubahan pada ruang yang sama, diferensiasi dan jumlahpembangunan dapat berpengaruh terhadap budaya politik yang dapat mengakomodasi budaya elite dan massa. Hal ini menunjukkan perubahan moderenisasi yang mulai berlangsung jika budaya mewah yangmenyebabkan perselisihan antara ruang kapasitas dengan ruang persamaan yang dari hari ke hari semakin menjulang dan terlihat sebagai tantangan bagi pemerintah dan juga rakyat.

Dari tahun 1980-an, negara-negara yang sedang berkembang cenderung bersifat disintegrasi usaha dalam mensejahterakan sistem demokrasi agar terhindar dari kurangnya disintegrasi. Usaha dalam pencegahan disintegrasi bangsa lebih relevan dan aktualapabila melewati pembelajaran pembangunan politik. Kata lain dari pembangunan politik yakni , pembaharuan politik, kependidikan poilitik, pengembangan, perubahan dan moderenisasi politik.

Dimensi persamaan pada pembangunan politik yang berhubungan dengan permasalahan keikutsertaan dan keterlibatan rakyat di berbagai pelaksanaan perpolitikan baik secara demokratis ataupun totaliter dan di ruang pelaksanaanya terikat 
oleh hukum yang universal, yaitu orang harus patuh kepada hukum dan dituntut adanya kesamaan serta prestasin tidak merupakan pertimbangan status berdasar sistem sosial politik yang tradisional. Ruang persaanini terkait oleh budaya politik, legitimasi yang berhubungan dengan sistem.

$$
\text { Sedangkan ruang kapasitas }
$$

merupakan kemampuan sistem politik yang ditinjau dari output yang telah dicapai serta berpengaruh besar yang terhadap sistem lain misal, halnya sistem sosial dan ekonomi. Ruang ini memiliki keterkaitan dengan wewenang resmi yang menjadi prestasi pemerintah, yang sebagian besar ruang lingkupnya dan tingkat penghargaan yang diraih pemerintahan, efektifitas pemerintah, efisiensi pelaksanaan kebijakan umum dan rasionalitas administrasi serta orientasi kebijakan tercerminkan.

Sedangkan dimensi diferensiasi dan spesialisasi memperlihatkan adanya struktur-struktur serta fungsi-fungsinya terdapat pada sistem politik. Dengan adanya deferensiasi maka akan bertambah kekhususan manfaat dari sebagian tokoh politik di dalam organisasi. Selain itu, diferensiasi memperlibatkan masalah integrasi dan proses yang rumit didasarkan pada perasaan integrasi.Sistem politik modernisasi menjadi lebih rumit serta sulitdikarenakan pelipatgandaan volume modernisasi politik. Dalam pengembangan peningkatan diferensiasi struktural dan spesialisasi fungsional Lembaga pemerintahan dan perilakurakyat perlu diubah serta keikutsertaan politik perlu diperbaiki.

Modernisasi politik masyarakat mengalami perubahan perilaku yang secara dramatis melalui perilaku sosial dan politik yang semula bersifat tradisional menjadi kearah modern. Modernisasi politik secara alami bertujuan untuk merubah masyarakat yang berkembang menjadi sejahtera, sehingga permasalahan yang muncul dari proses modernisasi politik yaitu tergesernya masyarakat tradisional kearah masyarakat modern. Akibat adanya modernisasi partisipasi dalam politik berlangsung di pedesaan hingga perkotaan yang dilakukan oleh sekelompok sosial yang meliputi masyarakat umum dan jajaran politik baru, seperti partai politik yang mengkoordinir keikutsertaan politik. Teori modernisasi juga memiliki kelemahan atau kekurangan yaitu :

a. Tidak dapat menggambarkan kepastian hari yang akan datang atau masa depan modernitas.

b. Modernisasi tidak dapat memperkirakan apa saja kegiatan 
yang akan terjadi didalam masyarakat.

c. Modernisasai tidak dapat memberikan alasan dan bagaimana negara berkembang bisa mengikuti pembangunan seperti negara-negara maju.

d. Modernisasi tidak memperhitungkan bagaimana bisa terjadi kemacetan, kemunduran, stagnasi maupun keterbelakangan pembangunan terutama di negara-negara berkembang.

Pada zaman keterbukaan ini banyak masalah sedang menjadi bahan atau menjadi bahan diskusi yang dulu jarang dibicarakan secara terbuka.masalah yang dulu dianggap sensitif untuk dibahas secara krisis masalah kini dapat ditelaah kembali.

Di dalam politik orde baru ciri khasnya padapelembagaan tokoh sosial politik ABRI, sistem perwakilan, kepartaian tidak terbuka, paksaan yang ada pada sentralisasi pemerintahan, serta orientasi pembangunan pada perkembangan ekonomi. Politik orde baru dapat dikatakan sukses apabila menumbuhkan keseimbangan politik yang cukup lama. Namun setelah berumur sekitar 30 tahun, timbul pernyataan-pernyataan fundamental. Seperti seberapa jauh politik dapat mencegah peningkatan aspirasi dan keinginan masyarakat terhadap demokrasi dan transparansi politik, Pemerintahan yang bersih, HAM, pemerataan dan keadilan sosial. Seperti halnya di era ini dicirikan dengan semakin banyak muncul arus globalisasi dengan paksaan bersyarat dan prinsip fairness, transparasi dan persaingan hubungan ekonomi politik antar negara. yang menjadi permasalahannya disisi cerita keberhasilan stabilitas politik danpertumbuhan ekonomi, tatanan politik orde baru ini ditandai dengan semakin merosotnya kedudukan masyarakat, ketimpangan sosial ekonomi yang selalu bertambah, dan semakin kuatnya gejala monopoli-oligopoli, korupsi serta kolusi politik ekonomi. Dampak yang langsung dari moderenisasi terhadap masyarakat tradisional ialah pembentukan peranan baru yang terlekat dengan proses menjadi modern. Namun peranan baru tersebut mungkin hanya sebagian saja yang baru, yang sifatnya menyesuaikan diri. Moderenisasi yang berlangsung di dalam hiraki kekuasaan dan prestisa harus cukup luas untuk menerobos yang bersifat tradisional dan akomodasionis.jika tidak, peran-peran baru akan menggantikannya.

Sistem mobilisasi pengembangan sektor modernisasi, mengubah hubungan kekuasaan dan prestise antara peran- 
peran.Sistem ini mengajukan sasaransasaran industrialisasi yang tidak realistik dan sangat tergantung pada paksaan.Sistem mobilisasi cenderung merupakan sistem dengan perasaan yang lebih tinggi dibanding sitem rekon siliasi, yang berakibat hilangnya informasi. Dengan hilangnya informasi membuat ketidakpastian dalam pembuatan keputusan dan pembatasan pilihan juga akanrekonsiliasi, mengakibatkan hilangnya informasi. Dengan hilangnya informasi tersebut membuat ketidakpastian dalam pembuatan keputusan dan pembatasan pilihan juga akandidesakkan karena pemerintah mengabaikan semua kemungkinan alternatif yang relevan.

Kurangnya informasi akan meningkatkan ketidak teraturan politik yaitu kondisi ketidakpastian itu sendiri. Bahkan, renzim-renzim yang mendewakan ilmu pengetahuan dengan menempatkan rasional erat-erat didalam pusat alam ini sekalipun yang bisa ditandai dengan ketidakstabilan dan irrasionalitas.

Sistem mobilitas juga bisa bergerak kearah totalitarianisme yang lebih besar dan ke arah tipe kolektivitas suci yang murni.Sebagian tipe kontrol tersebut memerlukan teknologi yang lebih maju dan stafmenejerial atau masyarakat kecil yang sangat sederhana dengan demikian, tidak banyak kesempatan bagi masyarakat yang sedang menjadi moderen untuk menjadi masyarakat totaliter yang kuat.

Namun alasan yang lebih penting dan sepenuhnya teoritik, mengapa sistem mobilisasi mengalami kemunduran. Karenanya, paksaan yang sempurna mengandung informasi yang sempurna karena konflik tidak dimungkinkan dan setiap orang akan tunduk pada instruksi, ini berarti bahwa sampling politik berlangsung dalam sistem rekonsiliasi, dengan kemungkinan akan terus dikalkulasi. Ketidakpastian kurang karena informasi kurang.Paradoksnya bisa dipecahkan jika kita menganggap bahwa pengetahuan yang dimiliki oleh pemimpin politik sistem mobilisasi di peroleh dari luar sistem dan terangkai semasa periode sebelumnnya dan dalam tipe sistem yang berbeda.

Dengan demikian, dalam sistem mobilisasi, disatu pihak rangsang diterministik dibatasi karena kebutuhan akan informasi baru akan menyesuaikan diri dengan kompleksitas yang semakin meningkat, sedangkan di pihak lain karena kebutuhan untuk mengetahui bentuk paksaan apa yang diperlukan. Maka dari itu sistem mobilisasi beralih menjadi sistem deterministik semiu yang berdasarkan informasi luar tetapi pengetahuan tidak 
timbul dengan sendirinya.Ia pun juga harus menyesuaikan diri dengan ketidakpastian. Akibatnya terjadilah manifes dalam tindakan yang tak terduga dari pemerintah, intimidasi, dan paksaan yang lebih jauh.

\section{PENUTUP}

\section{Kesimpulan}

Berdasarkan penelitian yang telah dilakukan sekitar tahun 1990-an, pada masa Orde Baru berbagai macam kalangan menghadapi paksaandari demokratisasi yang lumayan besar.Hak asasi manusia dan demokrasi mengalamiIsu yang sempat menjadi tren untuk bergerak pada masa orde baru . Pada era itu, telah banyak munculnya generasi-generasi baru seperti LSM hak asasi manusia serta demokrasi yang telah memperjuangkan dengan gigih untuk menyuarakan tuntutan tentang hak asasi manusia dan demokrasi yang diaggapuniversal .

Mahasiswa sebenarnya telah mengetahui tentang masalah perpolitikan melalui pendidikan di sekolah. Tanpa pendidikanpun mahasiswa juga sudah mengetahui masalah politik yakni melalui media masa maupun dari internet.Namun seiring berkembangnya zaman mahasiswa banyak yang lalai tentang pentingnya politik di dalam kehidupan bermasyarakat, contohnya ketika akan memilih seorang pemimpin seperti halnya dalam pemilihan presiden, banyak lebih memilih money politik tanpa memikirkan dampak atau akibat yang akan terjadi tentunya itu tidak gratis karena dengan adanya money politik pihak calon pemimpin pun tidak mau rugi dengan cara menggelapkan uang negara, maka dari itu kita sebagai mahasiswa harus pandai-pandai memilih pemimpin yang bertanggung jawab serta bijaksana di dalam dunia perpolitikan.

Saran:

Solusi yang dapat dilakukan untuk para mahasiswa pada era modernisasi terhadap ideologi pancasilasaat iniadalahdengan meningkatkan pemahaman tentang pancasila yakni dengan:

a. Membuat penyajian atau dalam pembelajaran dibuat semenarik mungkin untuk menimbulkan perhatian mahasiswa agar bisa menerapkan akan arti pentingnya pancasila dalam kehidupan seharihari.

b. Seiringnya perkembangan teknologi yang lebih maju, diharapkan para mahasiswa dapat mempublikasikan pentingnya berpartisipasi, berdemokrasi, serta dalam berpolitik. 


\section{DAFTAR PUSTAKA}

Altbach,Philip G. (1981). Politik dan Mahasiswa. Jakarta.: Gramedia

Apter, David E. (1965).Politik moderenisasi. Jakarta. PT Gramedia.

Cahyo,Cheppy Hary. (1986) Ideologi Politik. Yogyakarta: Pt. Hanindita Graha Widya.

Muhaimin,Hendro.(2013). Indonesia Naw.Between pancasila and crisis of democracy in indonesia. International Journal for public management ands politic development.

Mutaqin, Zeen Zaenal. (2017). The Story State and Pancasila: Reflecting Human Rights in the Indonesian Democracy. International Jurnal of the Strong State and Pancasila Reflecting Human Rights in the Indonesian Democracy.

Pabottinggi, Mochtar. (1996). Menelaah Kembali Format Politik Orde Baru. Jakarta. PT Gramedia Pustaka Utama.
Yuliani, Dian dan Sugiaryo. (2016). Hubungan Kesadaran Politik dan Divic Disposition Dengan

Partisipasi Politik Pemilih Pemula Dalam Pelaksanaan di Desa Klodra.Surakarta.Universitas Slamet Riyadi Surakarta.

Valiana, Anna dan Anita Trisiana. (2016). Analisis Strategi Komunikasi Politik Terhadap

Partisipasi PolitikPemenangan

Rudi dan Purnomo Dalam Pilkada.Surakarta.Universitas

Slamet Riyadi Surakarta.

Wartoyo, Anita Trisiana. (2017). Integrasi Pendidikan Karakter Dalam Pembelajaran Pendidikan Kewarganegaraan Untuk Meningkatkan Kedisiplinan Mahasiswa Universitas Slamet Riyadi Surakarta.Surakarta. Global Citizen, Vol 4: Des, 2017

Weatherbee, Donald E. (1985). Indonesia in 1984; Pancasila, Politic, Power. International Jurnal Of University Of California Press. 